\title{
Pedagogical Conditions for the Language Competence Development in Officers of the System of the Ministry of Internal Affairs of Ukraine in the Process of Continuous and Distance Learning
}

\author{
Iryna Trubavina ${ }^{1, *}, V^{1}$ olodymyr Liutyi ${ }^{1}$, Liudmyla Nepipenko ${ }^{1}$ and Svitlana Boiko ${ }^{2}$
}

${ }^{1}$ National Academy of the National Guard of Ukraine, Zakhysnykiv Ukrainy square, 3, Kharkiv, 61001, Ukraine

${ }^{2}$ Kharkiv National University of Internal Affairs, L. Landau avenue, 27, Kharkiv, 61080, Ukraine

*Corresponding author. Email: trubavina@gmail.com

\begin{abstract}
The course taken by Ukraine for European integration, NATO membership and cooperation with employees of the world security institutions in today's environment requires the language competence development in officers of the system of the Ministry of Internal Affairs in the process of distance learning. But the officers distance learning is absent in Ukraine due to the need to maintain the secrecy of officers and the lack of servers with Ukrainian data registration. The purpose of the research is to develop and experimentally test the model of language competence development in officers of the system of the Ministry of Internal Affairs of Ukraine and pedagogical conditions of the model implementation. Scientific novelty includes the model of language competence development in officers in the process of distance learning with its scientific approaches, purpose, principles, content of distance learning, which is differentiated by the specific officers' missions and routine, technologies, means, methods and forms of distance learning as well as pedagogical conditions of model implementation. The list of distance learning tools, technologies and autonomous educational platforms for learning a foreign language remotely by officers has been updated. The results are the pedagogical conditions of the model implementation which initiate the model and follow it during all time of training. They are following: development and implementation of new educational and methodological groundwork for distance learning, development and formation of digital competence in teachers and digital literacy in officers-students, development of positive motivation in officers to foreign languages. The efficiency of the model and pedagogical conditions of language competence development in officers in the process of distance learning is experimentally proved. Prospects for research is to develop a model of Ukrainian language distance learning for the foreign officers.
\end{abstract}

Keywords: distance learning, officers language competence, pedagogical conditions, model of language

competence development in officers in the process of distance learning

\section{INTRODUCTION}

The course taken by Ukraine for European integration, NATO membership requires mastering of foreign languages by officers of the system of the Ministry of Internal Affairs (MIA), including Police, the National Guard of Ukraine (NGU), and the Border service. Their responsibilities include interaction with foreign officers during hostilities, exercises, exchange of experience, training, protection of consulates, protection of the rights of foreigners in Ukraine, etc. During the pandemic, there was a need for continuous distance learning for officers, which is difficult in Ukraine due to the ban on officers registering on foreign platforms with servers outside Ukraine. Armed formations and higher military education institutions do not have their own training web-platforms with servers in Ukraine. So, there is a problem - how to organize continuous foreign languages distance learning of officers? This is what our research is aimed at.

\section{PROBLEMS AND METHODOLOGY}

We found out that the problem of distance learning of the officers of the Ministry of Internal Affairs system in foreign languages is insufficient, in particular, regarding the model of distance learning and pedagogical conditions of development of language competence in officers of military units of the system of the Ministry of Internal Affairs in the process of distance learning. Existing research reveals following: the language competence of officers $[1 ; 2 ; 3]$, which, however, do not show the 
specifics of officers of the Ministry of Internal Affairs, its various armed forces; approaches of language competence development in cadets $[4 ; 5]$, but do not show this for distance learning of officers [6;7]; the state of readiness of teachers of humanities for distance learning [8]. Foreign researches $[9 ; 10]$ reveal the methods of teaching foreign languages, but not officers of the Ministry of Internal Affairs, although some developments have become the basis of our research. Thus, we relied on the stages of learning foreign languages [11], used modern methods of teaching foreign languages [12]. Thus, the problem of distance learning in foreign languages of officers of the system of the Ministry of Internal Affairs is relevant and insufficiently developed. The analysis of research allowed us to make the following generalizations: the language competence of an officer of the Ministry of Internal Affairs is an integrative formation of personality that allows a specialist (officer) to effectively communicate in another language, to achieve positive results in their professional activities and the distance learning of officers of the Ministry of Internal Affairs is another type of training with a special form, which provides for extraterritorial interaction of subjects with the use of psychological and pedagogical, information and communication technologies and digital information and educational resources, allows interactive classes with different numbers of people, individual communication between the subjects and objects of learning united by a common goal synchronously and asynchronously, is realized in a specialized environment with the help of technical means of communication and is characterized by intensification, activation and individualization of learning [13]. It is important to intensify training in terms of accelerating training and saving time of officers, while we relied on research on its essence and ways of implementation in the educational process [14]. We needed to intensify our attention in the context of better assimilation, saving time and we relied on the research of V. Lozova [15]. Individualization of language learning is the implementation of the activity approach to learning, as skills are formed only in personal activities for the knowledge application.

We empirically studied the state of language competence development in NGU officers as part of the Ministry of Internal Affairs system in different regions of the country. And a total of 150 officers agreed to the survey and use a foreign language in their daily service. It was found that the state of language competence development does not sufficiently meet the needs of the NGU. Similar results were obtained through a survey of 122 police officers who were on advanced training courses at the Kharkiv National University of Internal Affairs. Thus, the distance learning of the officers of the system of the Ministry of Internal Affairs requires the development of a model of language competence development in officers in the process of distance learning and the pedagogical conditions that initiate the model in the educational process. It is the development of this model, substantiation and experimental verification of pedagogical conditions of its implementation for the language competence development in officers have become the purpose of our article. The methodology of our research includes scientific approaches used in the study, selection of criteria, indicators, levels of language competence development in officers and adequate research methods. There were chosen such scientific approaches for our research as systemic, androgynous, competency-based and informational.

The research methods were chosen such as pedagogical experiment, surveys, and standard questionnaires. The selected methods met the selected criteria of experimental work and the structure of the Ministry of Internal Affairs officer language competence.

We identified such criteria as motivational, contentcognitive, activity-communicative and control-evaluation. Indicators of the motivation criterion were identified such as awareness of officers of the requirements related to the professional language competence development, cognitive interest in learning a foreign language, desire for professional development, self-education, motives for responsibility, realization of personal potential, learning foreign languages (professional, social, and cognitive). Methods of research of this criterion development were following questionnaire for clarification of motives of studying of a foreign language (the survey developed by authors), monitoring.

We studied the content-cognitive criterion on the following indicators: knowledge of lexical and phraseological units in accordance with the outlined topics, which are considered as a necessary reserve for language comprehension during reading and oral communication, knowledge of grammatical rules in normative grammar, word combinations, thus, grammatical and lexical phenomena are considered in unity as a means of solving speech problems, knowledge of norms and standards of military communication in a foreign language, knowledge of means and methods of establishing, maintaining and completing speech contact to achieve a goal. The research methods for this criterion were NATO STANAG 6001 standardized language test and tests for completeness of knowledge.

Indicators of the activity-communicative criterion were following: understanding the conversation on social and personal professional topics and complete comprehension of the content while communicating (if the conversation is in common language at a normal pace, with few repetitions and paraphrases with the interlocutor who is a native speaker without experience communication with representatives of foreign cultures); the ability to clearly and concisely express opinions, persuade, argue, build evidence, analyze, make judgments in a foreign language, the ability to verbal interaction during combat missions; the ability to understand words and phrases that sound unfavorable conditions (for example, through a loudspeaker on the street or in a situation of increased emotional stress); the ability to understand while reading authentic texts on familiar topics; the ability to self-search professional communication; the ability to provide written information; the ability to organize and maintain dialogue 
in a foreign language, understanding the conversation on social and professional topics and complete comprehension of the content while communicating (if the conversation is in common language at a normal pace, with few repetitions and paraphrases with the interlocutor who is a native speaker without experience communication with representatives of foreign cultures). A standardized language test in accordance with the NATO STANAG 6001 became a method of studying the formation of the language competence according to this criterion.

We researched the control and evaluation criterion on the basis of the ability to consciously control the results of their activities, possession of a sufficient level of reflexive skills through the use of M. Snyder's method, and O.
Sergeenkova's survey "Diagnosis of self-control in communication».

The defined criteria and their indicators make it possible to identify three levels of MIA officer language competence as low, high, medium, which differ in the correctness of answers, complexity and scope of tasks, stability of motivation and motives for language learning, self-control and reflection.

\section{RESULTS AND DISCUSSION}

We have developed a model of language competence development in officers in the process of distance learning (Figure 1).

\begin{tabular}{|c|c|c|c|}
\hline \multicolumn{4}{|c|}{$\begin{array}{l}\text { Scientific approaches to distance learning in foreign languages of NGU officers: } \\
\text { systemic; andragogic; activity; competence; informative }\end{array}$} \\
\hline \multicolumn{4}{|c|}{ Objective: language competence development in NGU officers in the process of distance learning } \\
\hline \multicolumn{3}{|c|}{ Principles } & \multirow{2}{*}{ 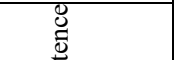 } \\
\hline didactic & \begin{tabular}{|c|} 
distance learning \\
\end{tabular} & foreign languages distance learning & \\
\hline $\begin{array}{l}\text { Individualization of training; } \\
\text { scientificity; experiential learning; } \\
\text { accessibility; systematic and } \\
\text { cognitive activity; independence } \\
\text { and positive motivation to learn; } \\
\text { regularity; student-centeredness; } \\
\text { clarity; learning optimization; } \\
\text { flexibility. }\end{array}$ & $\begin{array}{l}\text { Informatization of education; efficiency; } \\
\text { modularity; multimedia; social equality; ensuring } \\
\text { information security; adequacy of developing } \\
\text { skills training technologies; organization of } \\
\text { personal communication in the educational } \\
\text { process; adaptability and regulation. }\end{array}$ & $\begin{array}{l}\text { Self-organization and self-learning; } \\
\text { parallelism; manufacturability; quality; } \\
\text { modernity; internationality; adaptability of } \\
\text { learning; personality, constructiveness, } \\
\text { constancy, community of affairs; cognitive- } \\
\text { intellectual orientation, intercultural orientation } \\
\text { of learning, organization of collective } \\
\text { communication, the principle of "Low } \\
\text { threshold, high ceiling, wide walls", etc. }\end{array}$ & 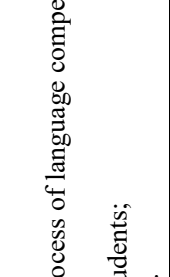 \\
\hline \multicolumn{3}{|c|}{ The content of foreign languages distance learning, taking into account the NGU specific tasks } & 苔 \\
\hline reading & \multicolumn{2}{|c|}{\begin{tabular}{|c|c|r|} 
speaking & writing & listening \\
\end{tabular}} & 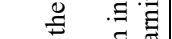 \\
\hline \multicolumn{3}{|c|}{ According to the specifics of the NGU tasks } & \\
\hline \multicolumn{3}{|c|}{ Technologies } & 胥 \\
\hline didactic & distance learning & foreign languages distance learning & Eี స్త్ర \\
\hline $\begin{array}{l}\text { traditional education; } \\
\text { problem-based learning; } \\
\text { collective learning. }\end{array}$ & $\begin{array}{l}\text { Collaborative learning; cooperative learning } \\
\text { technologies; work in groups; modular training; } \\
\text { BYOD; adaptive learning; virtual learning } \\
\text { environment; mobile learning; "Cloud" training; } \\
\text { design technology. }\end{array}$ & $\begin{array}{l}\text { Internet-oriented pedagogical technologies, } \\
\text { correspondence friends, joint creative work, } \\
\text { meetings with experts, J. Keller's ARCS, } \\
\text { gamification. }\end{array}$ & 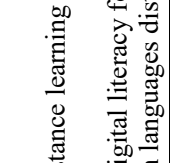 \\
\hline \multicolumn{3}{|c|}{ Methods } & تี ప్ \\
\hline $\begin{array}{l}\text { Organization and implementation } \\
\text { of educational and cognitive } \\
\text { activities; stimulation and } \\
\text { motivation of learning; control and } \\
\text { self-control in learning; problem- } \\
\text { based learning; verbal, visual, } \\
\text { practical. }\end{array}$ & $\begin{array}{l}\text { Methods of individualized teaching and learning; } \\
\text { methods based on the provision of educational } \\
\text { material to students by a teacher or expert, in } \\
\text { which students do not play an active role in } \\
\text { communication (learning "one to many"); } \\
\text { methods, which are characterized by active } \\
\text { interaction between all participants in the learning } \\
\text { process (learning "many to many", the method of } \\
\text { complete physical response, the method of } \\
\text { projects. }\end{array}$ & $\begin{array}{l}\text { Task-based learning; presentation-practice- } \\
\text { production; lexical method; method of } \\
\text { functions; communicative methods; grammar- } \\
\text { translation method; method of complete } \\
\text { physical reproduction; method of suggestive } \\
\text { discovery; content-based learning; language } \\
\text { learning through integration. }\end{array}$ & 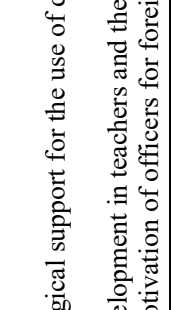 \\
\hline \multicolumn{3}{|c|}{ Forms } & $\sum_{0}^{0} @$ \\
\hline $\begin{array}{l}\text { individual; group; } \\
\text { frontal; steam. }\end{array}$ & $\begin{array}{l}\text { Consultations (individual, group; technical base: } \\
\text { e-mail, forums, chats); projects (group, individual } \\
\text { research, creative, information; technical base: all } \\
\text { Internet services); laboratory and practical } \\
\text { classes; individual (homework) (essays, essays, } \\
\text { tasks and others); control (online testing, exams, } \\
\text { credit; requires specialized software); games } \\
\text { (educational, role-playing and others); situational } \\
\text { analysis (case study); facilitation. }\end{array}$ & \begin{tabular}{|l} 
Virtual classroom; \\
Flipped Classroom. \\
\end{tabular} & 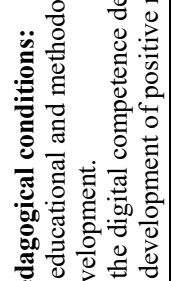 \\
\hline \multicolumn{3}{|c|}{ Tools } & \\
\hline
\end{tabular}


\begin{tabular}{|l|l|l|l}
\hline Teacher's word; special technical & Means of digital technologies, means of working & Asynchronous and Synchronous tools.
\end{tabular}

means of training; screen guides for with information: hypertext, multimedia and

static projection, video recording, hypermedia; teaching aids, information-

radio and television programs; communication technology tools; means of

computer (electronic dictionaries; distance learning organization.

electronic textbooks; audiovisual

textbooks; electronic versions of

printed dictionaries and manuals).

Result: increase in the level of National Guard of Ukraine officers language competence

Figure 1. Model of language competence development in officers in the process of distance learning.

The pedagogical conditions of the language competence development in officers in the process of distance learning we understand as the circumstances specially organized in the educational process of Higher educational institution, which provide influence on the formation and development of students of all components of language competence (organizational-motivational, cognitive, communicative and control-evaluation). The following pedagogical conditions for the language competence development in officers in the process of distance learning are defined as educational and methodological support for the use of language competence in officers in the process of distance learning, formation of digital competence of teachers in the use of remote technologies in education and for development of students digital literacy as well as motivation of students to distance learning in foreign languages. These pedagogical conditions initiate the whole language competence development in officers in the process of distance learning, and the success of their language learning depends on these pedagogical conditions. The pedagogical conditions also affect the whole process of distance learning, not only its individual stages, and they follow it at all stages of learning. The success of the entire distance learning educational process of officers depends on these conditions. All other pedagogical conditions that we identified in the process of survey and theoretical analysis of sources, did not have such a global impact on the development in the officers of the Ministry of Internal Affairs language competence, and addressed certain stages of learning. It was important to pilot them experimentally through their implementation into the educational process.

To test the effectiveness of pedagogical conditions, we conducted a pedagogical experiment in 3 stages: 1) indicative; 2) embracing; 3 ) summative - on the basis of the language department of the National Academy of NGU. A total of 68 officers were involved in the experimental study. All of them studied at the intensive foreign language courses at the National Academy of NGU. At the beginning of the experiment, all officers have approximately the same level of motivation, and the level of foreign languages is not lower than A2. They were divided into control and experimental groups depending on the level of foreign language proficiency. All 3 pedagogical conditions were introduced into the educational process of National Academy of NGU. The results of the experimental work are shown in table 1 .

Table 1. The results of experiment on the language competence development in NGU officers in the process of distance learning

\begin{tabular}{|c|c|c|c|c|c|c|c|c|c|c|}
\hline \multicolumn{11}{|c|}{ Increase according to the language competence motivational criterion } \\
\hline \multirow[b]{2}{*}{ No } & \multirow[b]{2}{*}{ Level } & \multicolumn{9}{|c|}{ Groups, number of students } \\
\hline & & $\begin{array}{l}\mathrm{EG}_{1} \\
(11)\end{array}$ & $\begin{array}{c}\mathrm{EG}_{4} \\
(5)\end{array}$ & $\begin{array}{l}\mathrm{CG}_{1} \\
(7)\end{array}$ & $\begin{array}{l}\mathrm{EG}_{2} \\
(10)\end{array}$ & $\begin{array}{c}\mathrm{EG}_{5} \\
(3)\end{array}$ & $\begin{array}{l}\mathrm{CG}_{2} \\
(10)\end{array}$ & $\begin{array}{c}\mathrm{EG}_{3} \\
(8)\end{array}$ & $\begin{array}{c}\mathrm{EG}_{6} \\
(5)\end{array}$ & $\begin{array}{l}\mathrm{CG}_{3} \\
(9)\end{array}$ \\
\hline & & \multicolumn{9}{|c|}{ Growth rate } \\
\hline 1. & Low & $-27,3 \%$ & $-20 \%$ & $-14,3 \%$ & $-30 \%$ & $-100 \%$ & $-10 \%$ & $-25 \%$ & $-40 \%$ & $-11,1 \%$ \\
\hline 2. & Middle & $9,1 \%$ & $\frac{+20 \%}{-20 \%}$ & $\begin{array}{c}+14,3 \% \\
-14,3 \%\end{array}$ & $-10 \%$ & $33,3 \%$ & $10 \%$ & $-12,5 \%$ & $-20 \%$ & $\begin{array}{l}+11,1 \% \\
-11,1 \%\end{array}$ \\
\hline 3. & High & $18,2 \%$ & $20 \%$ & $14,3 \%$ & $40 \%$ & $66,6 \%$ & 0 & $37,5 \%$ & $60 \%$ & $11,1 \%$ \\
\hline \multicolumn{11}{|c|}{ Growth according to the language competence content-cognitive criterion } \\
\hline No & Level & \multicolumn{9}{|c|}{ Growth rate } \\
\hline 1. & Low & $-18,2 \%$ & $-60 \%$ & 0 & $-50 \%$ & $-33,3 \%$ & $-10 \%$ & $-37,5 \%$ & $-60 \%$ & $-33,3 \%$ \\
\hline 2. & Middle & $9,1 \%$ & $20 \%$ & $-14,3 \%$ & $10 \%$ & $\frac{+33,3 \%}{-33,3 \%}$ & $\frac{+10 \%}{-10 \%}$ & $12,5 \%$ & $20 \%$ & $22,2 \%$ \\
\hline 3. & High & $9,1 \%$ & $40 \%$ & $14,3 \%$ & $40 \%$ & $33,3 \%$ & $10 \%$ & $25 \%$ & $40 \%$ & $11,1 \%$ \\
\hline \multicolumn{11}{|c|}{ Increase according to the language competence activity-communicative criterion } \\
\hline No & Level & & & & & Irowth rat & & & & \\
\hline 1. & Low & $-27,3 \%$ & $-20 \%$ & $-28,6 \%$ & $-50 \%$ & $-66,6 \%$ & $-10 \%$ & $-37,5 \%$ & $-60 \%$ & $-33,3 \%$ \\
\hline 2. & Middle & $18,2 \%$ & $\frac{+20 \%}{-20 \%}$ & $14,3 \%$ & $20 \%$ & $33,3 \%$ & $\frac{+10 \%}{-10 \%}$ & $12,5 \%$ & $20 \%$ & $22,2 \%$ \\
\hline
\end{tabular}




\begin{tabular}{|c|c|c|c|c|c|c|c|c|c|c|c|}
\hline 3. & High & $9,1 \%$ & $20 \%$ & $14,3 \%$ & $30 \%$ & $33,3 \%$ & $10 \%$ & $25 \%$ & $40 \%$ & $11,1 \%$ \\
\hline \multicolumn{10}{|c|}{ Increase according to the language competence control and evaluation criterion } \\
\hline No & Level & \multicolumn{10}{|c|}{ Growth rate } \\
\hline 1. & Low & $-18,2 \%$ & $40 \%$ & $-14,3 \%$ & $-30 \%$ & $-33,3 \%$ & $-20 \%$ & $-37,5 \%$ & $-40 \%$ & $-22,2 \%$ \\
\hline 2. & Middle & $9,1 \%$ & $20 \%$ & $14,3 \%$ & $10 \%$ & $\frac{+33,3 \%}{-33,3 \%}$ & $10 \%$ & $25 \%$ & $20 \%$ & $11,1 \%$ \\
\hline 3. & High & $9,1 \%$ & $20 \%$ & 0 & $20 \%$ & $33,3 \%$ & 0 & $12,5 \%$ & $20 \%$ & $11,1 \%$ \\
\hline
\end{tabular}

Thus, we see that the results of the final diagnosis of the development of language competence in the officers of the experimental group indicate a positive trend in all criteria. At the same time, the positive motivation to study foreign languages in the process of distance learning was most influenced by the content of training, and the knowledge and skills as components of officers' language competence were most influenced by pedagogical and digital learning technologies, and digital teaching tools. The results of the experimental work were confirmed by the Student's criterion.

It should be noted that the successful implementation of the developed model and pedagogical conditions is already completed in the National Academy of NGU, and the implementation is under the process in the Kharkiv National University of Internal Affairs, Ivan Chernyakhovskyi National University of Defense of Ukraine, Peter Saghaidachnyi National Academy of Land Forces, National University of Civil Defense of Ukraine and Donbas State Pedagogical University. It should also be noted that after our pedagogical experiment implementation in the language department of National Academy of NGU, a British Council project was launched. It proved the need for distance learning officers to train teachers for such work through involving students in active interaction at online classes, digital literacy and competencies (both teachers and students) and students' feedback. This confirms the correctness of our conclusions and reasonable pedagogical conditions for the development of language competence in the officers.

\section{CONCLUSION}

The results of the experimental study confirmed the effectiveness of the organization of the process of language competence development in NGU in the process of distance learning with the help of a reasonable model and defined 3 pedagogical conditions. The study does not claim to fully reveal the problem of language competence development in NGU officers in the process of distance learning. The results prove the need for further theoretical and experimental research on student-centered approach in distance learning of NGU officers, and development of their language competence in blended learning as well as teaching Ukrainian to foreign officers.

\section{REFERENCES}

[1]Bohush, A. M., Tryfonova, O. S., Kysel'ova, O. I. (2008). Development of language identification at different age stages. $272 \mathrm{p}$.

[2]Lahodynskyi, O. S. (2013). English language competence as a component of cadets' English language training. Visnyk Natsionalnoi akademii Derzhavnoi prykordonnoi sluzhby Ukrainy. Vyp. 3. URL:http://nbuv.gov.ua/UJRN/Vnadps_2013_3_15.

[3]Krykun, V. D. (2018). Formation of foreign language professional competence of future masters of military management [Thesis of Doctoral dissertation, Ivan Cherniakhovskyi National University of Defence of Ukraine].

[4]Hridnyeva, L. M. (2010). Formation of foreign language communicative competence of future law enforcement officers [Thesis of Doctoral dissertation, Taras Shevchenko Lughansk National University].

[5]Mamonova, O. I. (2015). Contextual model of professionally oriented language training of future law enforcement officers [Doctoral dissertation, Taras Shevchenko Lughansk National University].

[6]Shevchenko, O., Gusak, Yu., \& Tikhonov, G. (2018). Analysis of the possibility of introducing distance learning technologies in the system of advanced training of officers of the Armed Forces of Ukraine. Modern information technologies in the field of security and defense, 2, p. 151-154. URL:

http://nbuv.gov.ua/UJRN/sitsbo_2018_2_26

[7]Goncharuk, V. (2010). Distance learning as a new form of training for law enforcement officers of Ukraine. Bulletin of Kharkiv National University of Internal Affairs, 1 (48). p. 292-298.

[8]Trubavina, I., Dotsenko, S., Naboka, O., Chaikovskyi, M. \& Meshko, H. (2021). Developing digital competence of teachers of Humanitarian disciplines in the conditions of COVID-19. Journal of Physics. URL: 
https://iopscience.iop.org/article/10.1088/1742$6596 / 1840 / 1 / 011001 / p d f$

[9]Defence Learning Network (2014). URL: https://www.canada.ca/en/department-nationaldefence/services/benefits-military/educationtraining/professional-development/defence-learningnetwork.html.

[10]Second language training in the Canadian Armed Forces (2019). URL:

https://www.canada.ca/en/department-nationaldefence/services/benefits-military/educationtraining/professional-development/second-languagetraining.html.
[11]Army: Serve \& learn (2020). Anglia Ruskin University. URL:

https://distancelearning.anglia.ac.uk/british-army/

[12]Start learning French for free with the live Lingua project (2020).

https://www.livelingua.com/french/courses/dli/

[13]Liutyi, V. (2021). Methodical recommendations on distance learning of foreign languages of officers of the National Guard of Ukraine. 56 p.

[14]Ryzhkova, A. \& Trubavina, I. (2012). Time management as a condition for intensifying the education of future economists in universities. $104 \mathrm{p}$.

[15]Lozova, V. \& Trotzco G. (2002). Theoretical foundations of education and training: $286 \mathrm{p}$. 